\title{
Effect of Vitamin C on the Hepatotoxicity Induced by Cisplatin in Rats
}

\author{
Rana M. Ahmad \\ Ahmad H. Al-Jawary \\ Department of Anatomy \\ College of Medicine \\ University of Mosul
}

(Received 10/ 10 / 2011 ; Accepted 12 / 12 / 2011 )

\begin{abstract}
Cisplatin drug is one of platinum compounds and it is in common use world wide for the treatment of a variety of human neoplasms. However in high doses it can produce undesirable toxic side effects on liver, so in this study we investigated whether vitamin C has protective effect on hepatotoxicity induced by cisplatin or not. Three equal-sized groups (six rats each) of adult male albino rats were used as a)- control group b)- recipient of cisplatin or c)- recipient of vitamin C, 24 hrs before cisplatin injection. Histological examination of livers were carried out using light microscopy. Results showed that cisplatin produced pathological changes manifested as severe fatty changes, congestion and dilatation of portal blood vessels and central veins, dilatation and congestion of sinusoids, with multiple necrotic foci and apoptotic cells, while prior administration of vitamin $\mathrm{C}$ produced amelioration of the pathological changes induced by cisplatin.
\end{abstract}

Key words: Cisplatin, Vitamin C, Liver.

\section{تأثيرفيتامين ج علسمية الكبد التي يحشها عقارلالسبلاتنين في الجرذلن}

\section{الملخص}

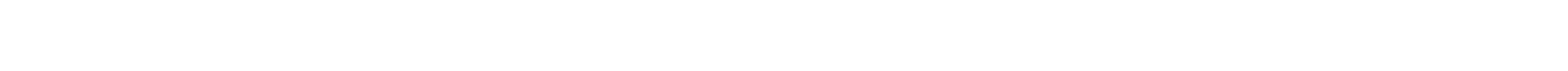

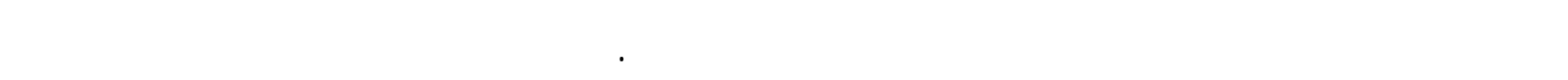

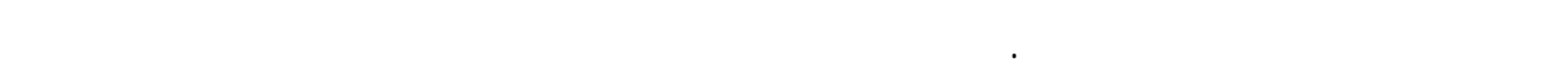

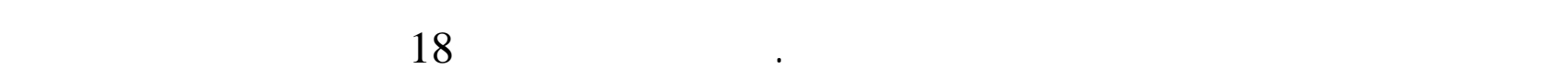

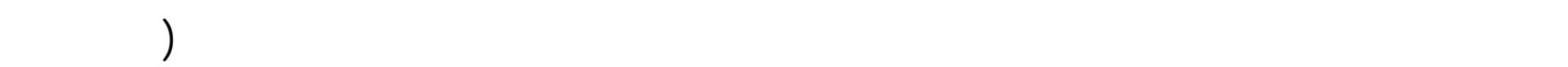

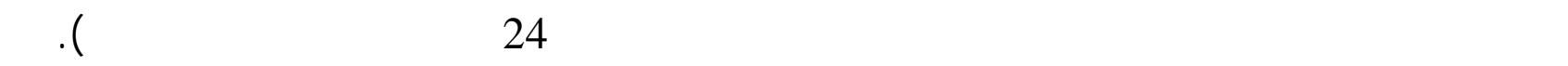

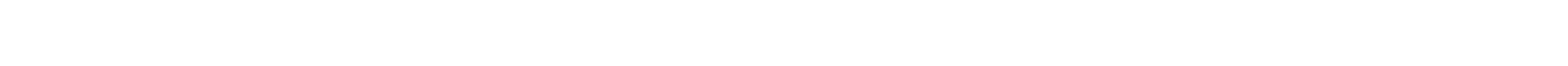

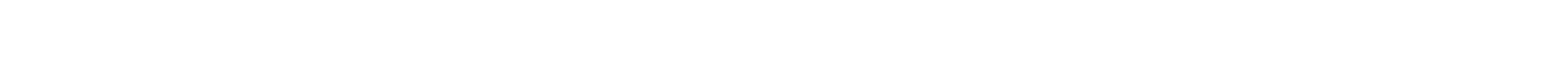

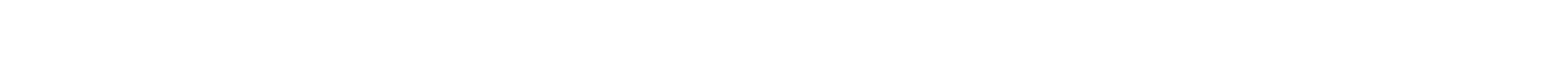




\title{
الموت الخلوي، بينما المجموعة المعلملة بفيتلمن ج قل الحتن بللسبلاتين فقد أظهرت تهسن في التغي _رات المرضية المستحثة بعقار اللسبلاتين.
}

\author{
الكاملت الدالة: عقار اللسبلاتين، فيتلمين ج، الكبد.
}

\section{INTRODUCTION}

Cisplatin is used as anti-neoplastic agent for the treatment of metastatic tumors and many other solid tumors (Sweetman, 2002). Although higher doses of cisplatin are more efficacious for the suppression of cancer, high dose therapy manifests irreversible renal dysfunction and other toxicities (Halliwell and Cross, 1994). There is a suggestion that the drug accumulates in significant amounts in hepatic tissue particularly when injected in high doses (Liu et al., 1998). Despite its excellent anticancer activity (Park et al., 2009), the clinical use of cisplatin is often limited by its undesirable severe toxic side effects that interfere with its therapeutic efficacy (Aly et al., 2003 ; Ajani et al., 2008 ; Dank et al., 2008). Extensive investigations have been conducted on the hepatotoxicity of this anticancer drug (Kim et al., 2004 ; Pal et al., 2008). These include biochemical studies of liver enzymes (Kim et al., 2005 ; Venkatesan et al., 2008). There is very limited information concerned with the effects of this drug on the histopathology and ultrastructure of liver cells (Mansour et al., 2006 ; Al-Majed, 2007 ; El-Sayyad et al., 2009 ; Abdelmeguid et al., 2010). Furthermore, a variety of agents including antioxidants have been shown to attenuate the hepatotoxicity of cisplatin (Yace et al., 2007).

Intake of antioxidant vitamins which are widely distributed in fruits could be beneficial in protection against hepatotoxicity (William, 1995). Vitamin C (vit C) is well known antioxidant, which can protect the body from damage caused by free radicals that can be generated during normal metabolism as well as through exposure to toxins and carcinogens (Banerjee et al., 2009). In the literature, we found no reports on the protective effect of vit $\mathrm{C}$ against cisplatin induced-hepatotoxicity. However, many studies reported that vit $\mathrm{C}$ supplementation could ameliorate cisplatin-induced acute renal failure in mice (Ajith et al., 2009), other article suggested that vit $\mathrm{C}$ reduced the oxidative stress induced renal failure (Ferretti et al., 2008). In the current study, the proposed plan aimed to asses and examine the possibility of vitamin $\mathrm{C}$, through its antioxidant property, to protect against and reduce the histopathological changes induced by cisplatin on normal liver tissues of male albino rats, which were used as biological test animals.

\section{Animals:}

\section{MATERIALS AND METHODS}

Healthy adult male Wistar albino rats of same age group (three months old) and weighing (200-220 mg) were selected for this study. These animals were kept at controlled room temperature $\left(23-25 C^{0}\right)$ with a 12 hours light/ dark cycle. Animals had free access to laboratory pellet foods and tap water.

Test Chemicals:

Cisplatin and vitamin C were obtained from the local markets, were cisplatin is purchased from Medical Centre Pharmacy in Mosul supplied by Cisplatin DBL ${ }^{\circledR}$, Hospira, 
and vitamin C was purchased from Dohuok and Arbil pharmacies supplied by Redoxon ${ }^{\circledR}$, BAYER.

\section{Experimental designs:}

The rats were divided into three groups consisting of six animals in each group. The rats in the first group were served as control and received $0.9 \%$ of normal saline only. The rats in the second group received single dose of cisplatin ( $6 \mathrm{mg} / \mathrm{kg}$ body weight) only. The rats in the third group received single dose of vitamin $C$ (100 $\mathrm{mg} / \mathrm{kg}$ body weight) one day prior to the cisplatin injection of the same dose received by the second group. Injections were given intra-peritoneally to rats. In the end of $2^{\text {nd }}$ day and in the $3^{\text {rd }}$ day half of the rats in the second group died while the remaining rats in the $2^{\text {nd }}$ group and the other two groups, all were killed in the fourth day as was programmed, by ether inhalation.

\section{Histological study:}

At the end of the experiment the liver of both control and treated groups were collected and fixed in 10\% neutral buffered formalin solution for 24-48 hours, the tissues were then dehydrated in ascending grades of alcohol solution starting by $70 \%$ for two hours and $90 \%$ for two hours then two change of absolute alcohol for two hours and over night, respectively. After that, the tissues were cleared by two changes of xylene for one hour each, and finally embedded in three changes of $\left(60 \mathrm{C}^{\mathrm{O}}\right)$ melting paraffin for one hour each. Five micron sections were obtained, stained with Harris hematoxylin and eosin and evaluated for any structural changes under bright field microscope.

\section{RESULTS}

Light microscopic study revealed that the control hepatic tissue showed normal large polygonal cells with round nuclei and eosinophilic cytoplasm arranged around central venules, and few spaced hepatic sinusoids arranged in between the hepatic cords with fine arrangement of Kupffer cells (Fig. 1). In contrast, groups receiving cisplatin only in the second group showed massive hepatotoxicity, in which the most pronounced histopathological abnormalities were severe fatty changes (Fig. 2), congestion in the central vein with diffuse sinusoidal dilalation and many apoptotic cells (Fig. 3) and many focal areas of necrosis mainly around central vein (Fig. 4). While the third group which received both vit $\mathrm{C}$ and cisplatin, the histopathological examination revealed regression in fatty changes in the cytoplasm of hepatocytes (Fig. 5). Scattered apoptotic cells were noticed (Fig. 6). Less focal areas of necrosis were seen and infiltration of numerous mononuclear inflammatory cells (MNCs) specially in the dilated sinusoids and around the interlobular septa (Fig. 7). 


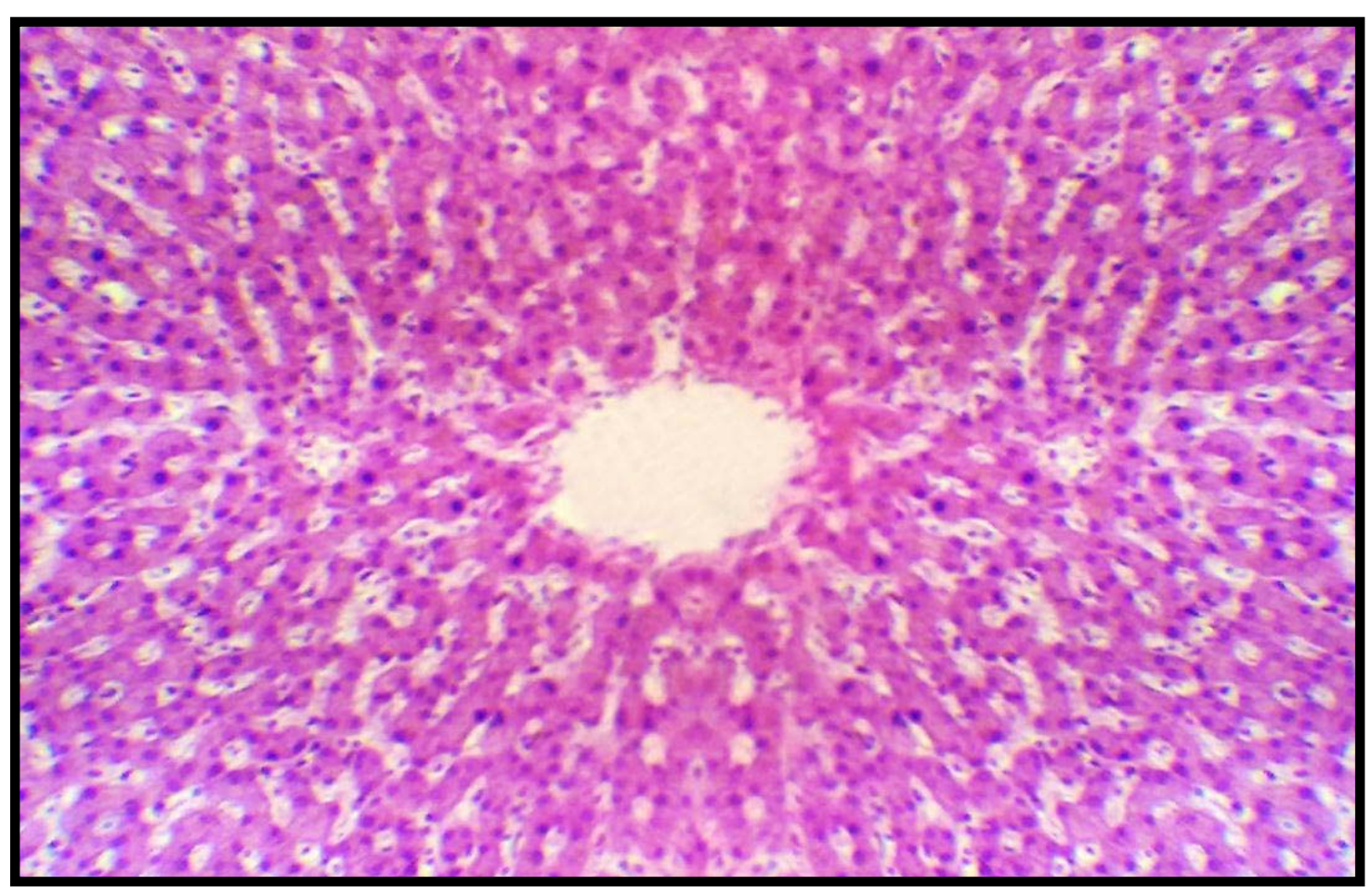

Fig. 1: Specimen rat liver showing normal histology of the liver (H\&EX100).

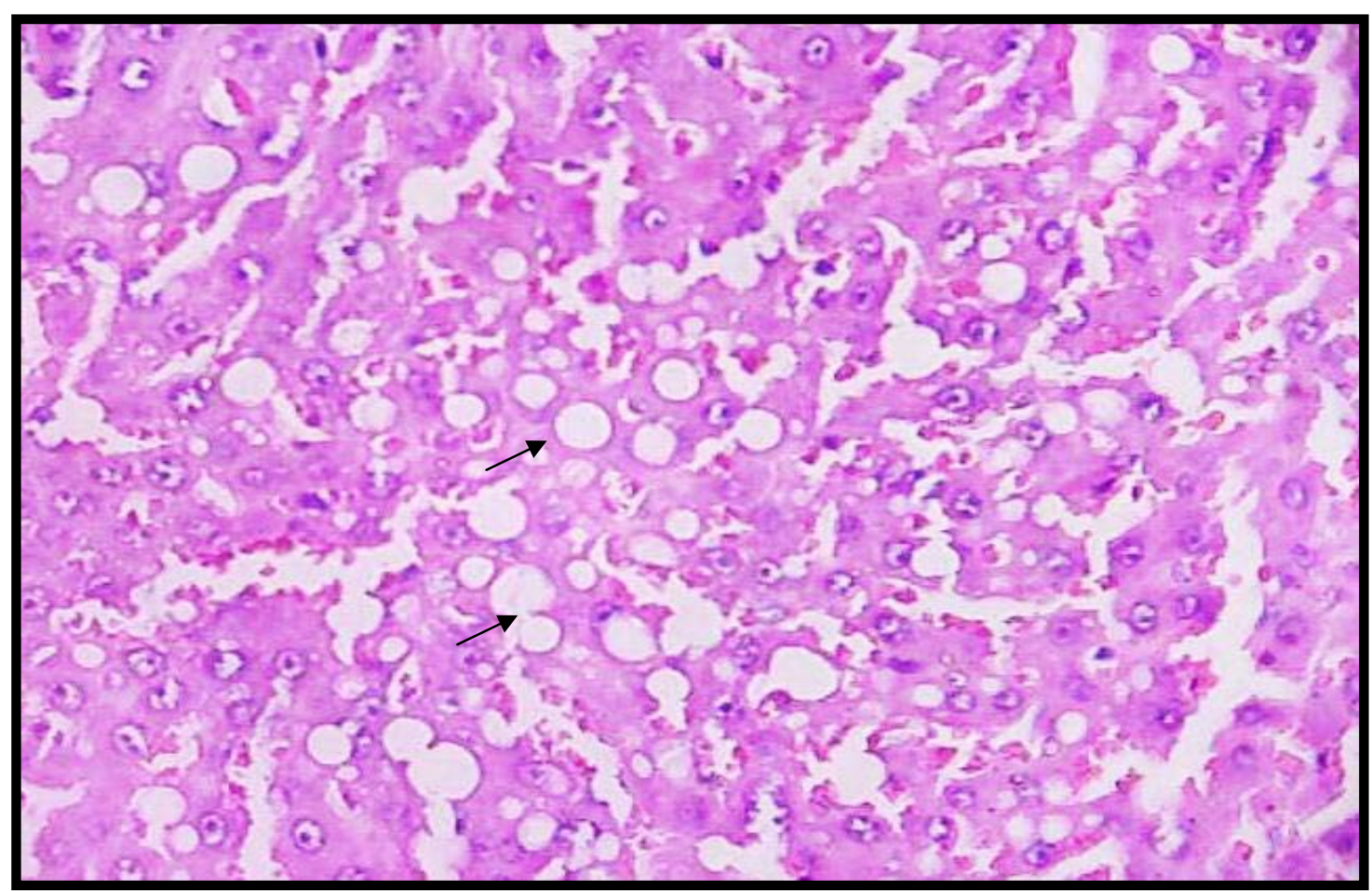

Fig. 2: Specimen rat liver treated with cisplatin only showing severe fatty changes (black arrows)(H\&EX400). 


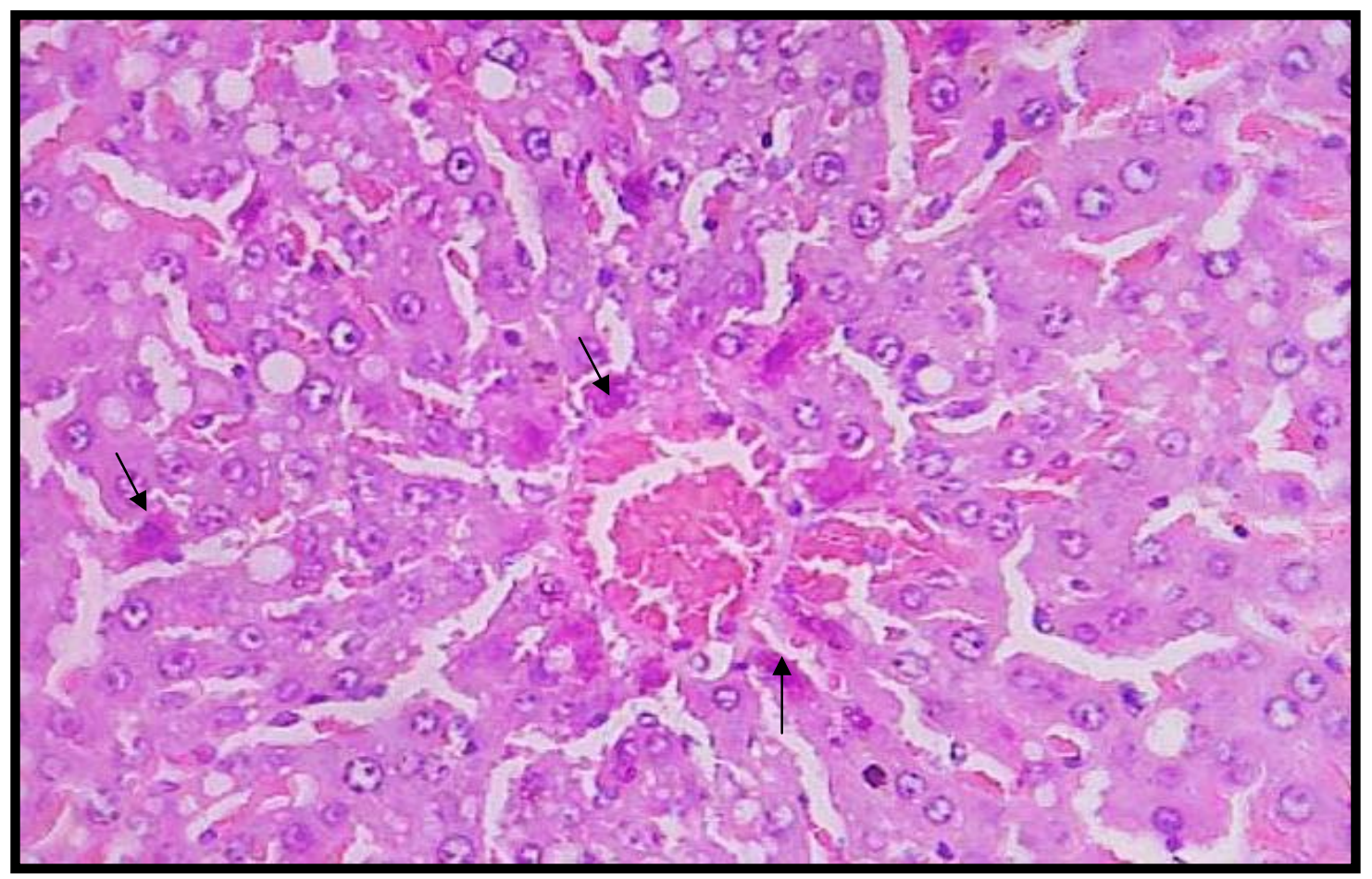

Fig. 3: Specimen rat liver treated with cisplatin only showing central vein congestion with sinusoidal dilatation and apoptotic cells (black arrows) (H\&EX400).

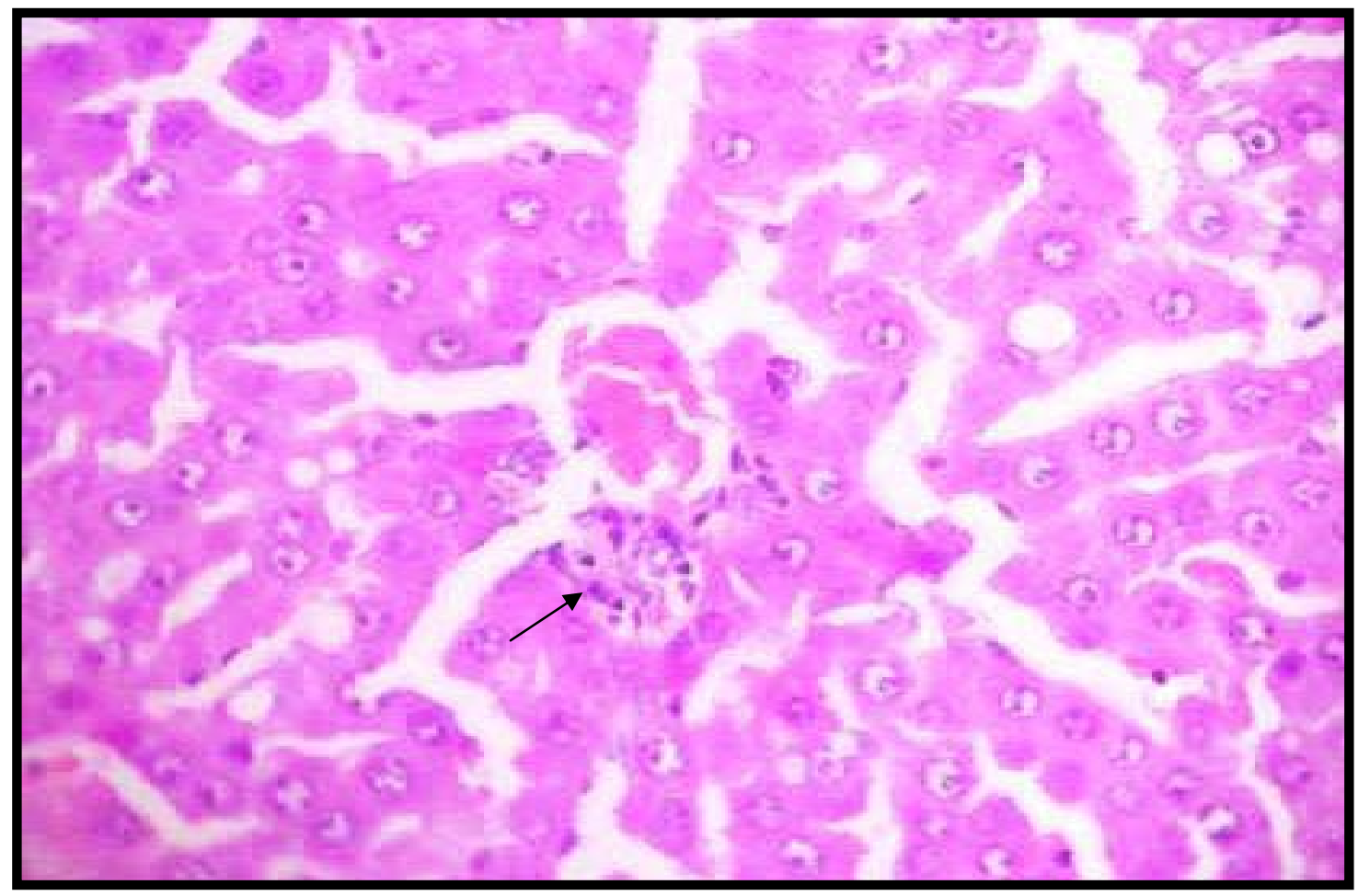

Fig. 4: Specimen rat liver treated with cisplatin only showing necrotic area with mononuclear cells infiltration near central vein (black arrow)(H\&EX400). 


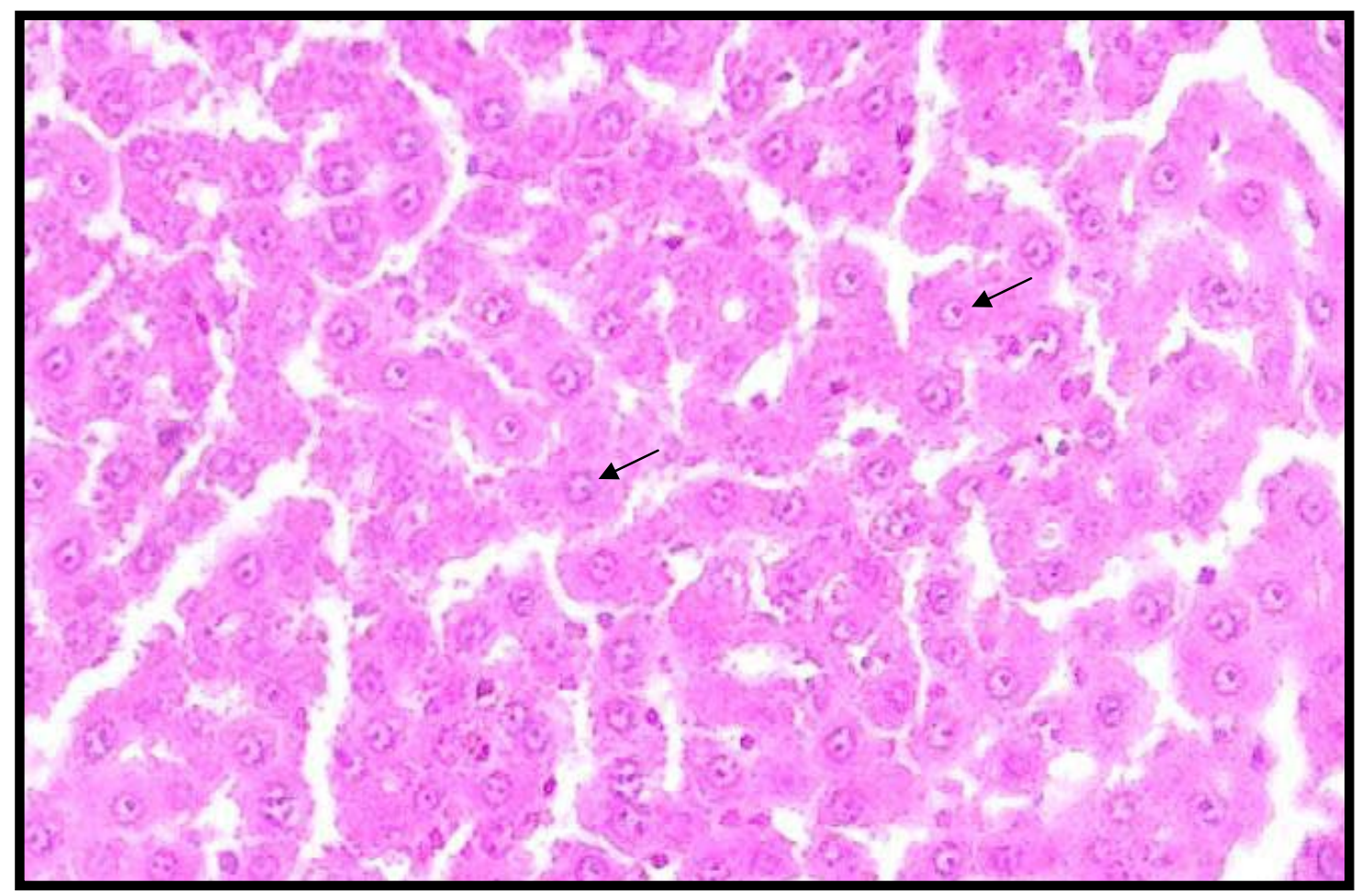

Fig. 5: Specimen rat liver treated with cisplatin and vit $C$ showing no fatty changes in cytoplasm of hepatocytes (black arrow)(H\&EX 400).

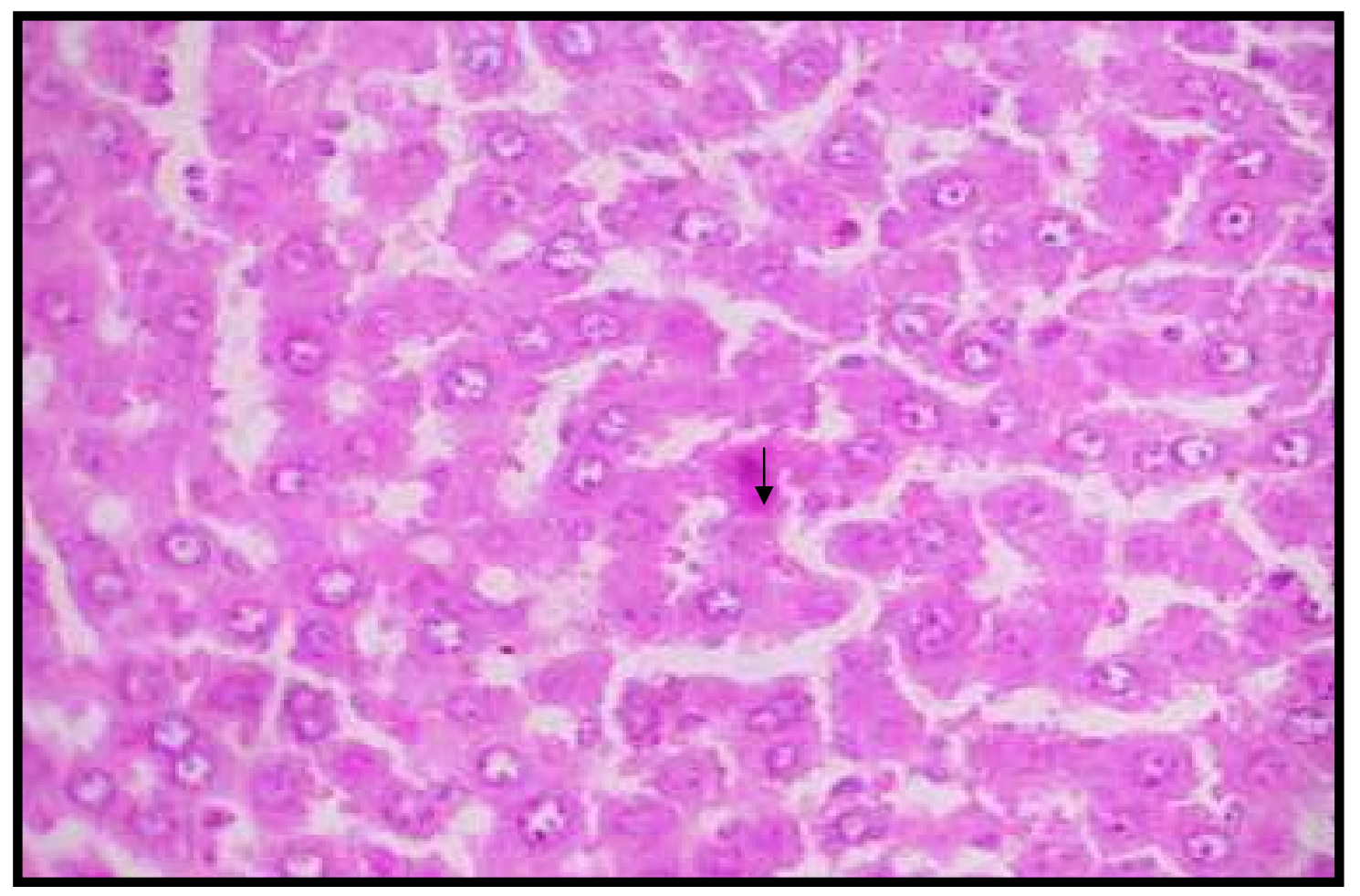

Fig. 6: Specimen rat liver treated with cisplatin and vit $C$ showing focal apoptotic cell (black arrow)(H\&EX400). 


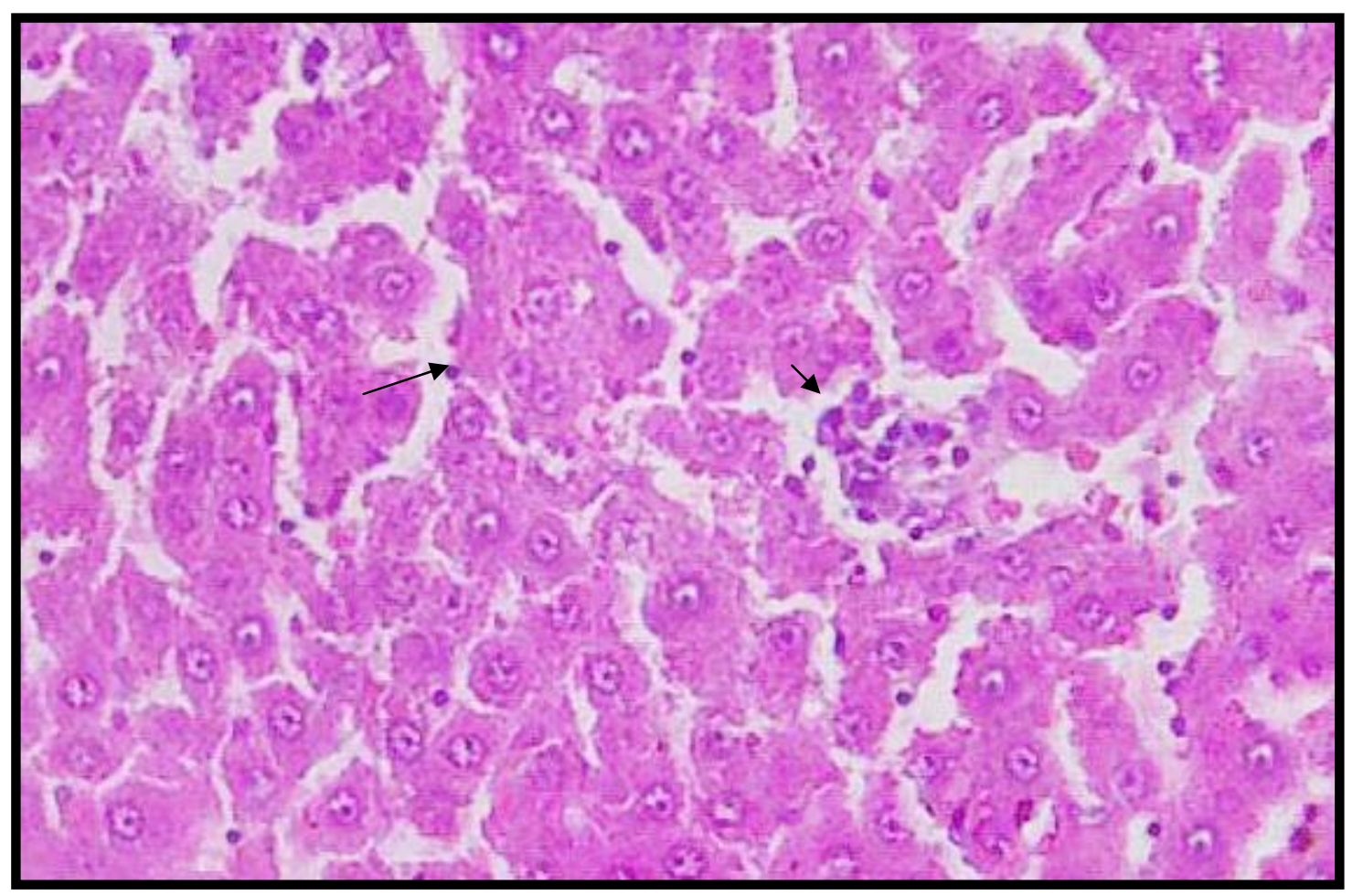

Fig. 7: Specimen rat liver treated with cisplatin and vit $\mathrm{C}$ showing focal necrotic area with mononuclear cells infiltration (arrow head) and in dilated sinusoids (black arrow)(H\&EX400).

\section{DISCUSSION}

The liver tissues of the control group in the present study revealed no deviation from the normal histological structure. Such findings were similar to those described by previous workers on rat liver (Amin and Hamza, 2005), on human liver (Fawcett and Jensh, 2002). In the treated group receiving single dose of cisplatin, half of rats died before reaching the end of treatment program and this might be due to nephrotoxicity because the kidney is the target organ of cisplatin (Revindra et al., 2010). The histolopathological results of this group represented by severe fatty changes and dilatation of sinusoids and central venules, these findings were in accordance with the experimental studies conducted by others (Abdelmeguid et al., 2010; Ahmed et al., 2010; El-Sayyad et al., 2009). These changes are mostly due to inflammation. Fatty changes were the land mark change in this group, this finding supported the previously reported by others (Koc et al., 2005; Ramachandran and Kakar, 2009; Abdelmeguid et al., 2010) where they described that following single toxic dose of cisplatin, the cytoplasm of most hepatocytes was light and filled with numerous vacuoles and lipid droplets. Zhang and Wang in (1984) suggested that, the cytoplasmic vacuolation is mainly a consequence to considerable disturbance in lipid and fat metabolism. Apoptosis was an important pathological change seen in this group and cisplatin might induced apoptosis via oxidative stress since apoptosis can be induced by the addition of reactive oxygen intermeditors (ROIs) or depletion of intracellular anti-oxidants (De Bono and Yang, 1995; Oral, 1997). Other investigators were in agreement with current 
study as they described the apoptosis was the main cytotoxic changes induced by cisplatin (Evans and Dive, 1993; Oral et al., 2000; Abdelmeguid et al., 2010; Ahmed et al., 2010). Necrosis was obvious change noticed in the current study which was more evident in this group this result is in accordance with that reported by El-Sayyad et al.(2009) in which they noticed necrotic tissues and apoptotic cells following treatment with cisplatin. The most common reaction leading to the cell necrosis is the formation of covalent bonds between a reactive metabolite of the parent compound and cell protein or DNA (Lee, 2003). The mechanism by which cisplatin-induced hepatotoxicity via oxidative stress as recent studies have suggested that oxidative stress plays an important role in cisplatin-induced liver damage (Lu and Cederbaum, 2006; Iraz et al., 2006; Pratibha et al., 2006), such oxidative stress resulting in the enhanced production of reactive oxygen species, reduction in the mitochondrial membrane potential (Saad et al., 2004) and decrease in antioxidant enzymes (Mora et al., 2003). Therefore, antioxidants administration before cisplatin treatment is essential to act against its toxicity (Lee et al., 2007).

The last group, which received both vit $\mathrm{C}$ and cisplatin, showed no cases of death. This reflected the benefit of vit C which is supported by (Cameron and Campbell, 1991; Khaw et al., 2001), as they found in patients with cancer who received vit C supplementation lived longer when compared to control group who did not receive any supplementation. So, in current group which received vit $C$ prior to cisplatin injection showed amelioration in the histopathological changes and this run in agreement with Atasayar et al. (2009) who demonstrated that combined treatment of vit $\mathrm{C}$ and $\mathrm{E}$ with single acute dose (toxic dose) of cisplatin $(7.5 \mathrm{mg} / \mathrm{kg}$ ) able to normalize the histopathological alteration induced by cisplatin on kidney when compared with cisplatin treated group.

The mechanism by which vit $\mathrm{C}$ decrease the hepatotoxicity induced by cisplatin, is embodied in the fact that vit $\mathrm{C}$ might ameliorate the oxidative damage by decreasing lipid peroxidation and altering antioxidant defense system (El-Gendy et al., 2010) or by denoting electrons to free radicals and quenching their reactivity (Bendich, 1990). In addition, ascorbate prevents hepatic glutathione depletion in chemical-induced hepatotoxicity in mice, in which glutathione acted as intracellular free- radical scavengers and protected cells against radical mediated lipid peroxidation (Cuddihy et al., 2008).

\section{REFERENCES}

Abdelmeguid, N.E.; Chmaisse, H.N.; Abou Zeinab, N.S. (2010). Silymarin ameliorates cisplatin-induced hepatotoxicity in rats: histopathological and ultrastructural studies. Pakistan J. Biol. Sci. 13(10), 463-479.

Ahmed, N.Z.; El-Deib, K.M.; Ahmed, M.M. (2010). Studies on curcuma longa, chicorium intybus and petroselinum sativum water extracts against isplatin-induced toxicity in rats. J. Amer.n Sci. 6(9) :545-558.

Ajani, J.A. (2008). Optimizing docetaxel chemotherapy in patients with cancer of the gastric and gastroesophageal junction: Evolution of the docetaxel, cisplatin and 5fluorouracil regimen. Cancer, 113: 945-955.

Ajith, T. A.; Abhishek, G.; Roshny, D.; Sudheesh, N.P. (2009). Co- Supplementation of single and multi doses of vitamins $\mathrm{C}$ and $\mathrm{E}$ ameliorates cisplatin-induced acute renal failure in mice. Exp. Toxicol. Pathol. 61, 565-571.

Al-Majed, A.A. (2007). Carnitine Deficiency Provokes Cisplatin-Induced hepatotoxicity in Rats. Basic Clin. Pharmacol. and Toxicol., 100, 145- 150. 
Aly, M.S.; Ashour, M.B.; El-Nahas, S.M.; Abo-Zeid, M.A. (2003). Genotoxicity and cytotoxicity of the anticancer drugs gemcitabine and cisplatin, separately and in combination: In vivo studies. J. Biol. Sci. 3, 961-972.

Amin, A.; Hamza, A.A. (2005). Oxidative stress mediates drug-induced hepatotoxicity in rats: a possible role of DNA fragmentation. J. Toxicol. 208, 367-375.

Atasayar, S.; Gürer-Orhan, H.;Gürel, B.; Girgin, G.; Özgünes, H. (2009). Preventive effect of aminoguanidine compared to vitamin $\mathrm{E}$ and $\mathrm{C}$ On cisplatin-induced nephrotoxicity in rats. Exp. Toxicol. Pathol. 61, 23-32.

Banerjee, P.; Bhattacharyya, N.; Bhattacharjee, S.; Boujedaini, A.R.; Khuda-Bukhsh, B. (2009). Ascorbic acid combats arsenic-induced oxidative stress in mice liver. Ecotox Eaviron. Safe. 72, 639-649.

Bendich, A. (1990). Antioxidant micronutrients and immune responses. Ann. NewYork Acad. Sci., 587, 68-180.

Cameron, E.; Campbell, A. (1991). Innovation versus quality control: An "unpublishable" clinical trial of supplemental ascorbate in incurable cancer. Med. Hypothesis 36, 185-189.

Cuddihy, S. L.; Parker, A.; Harwood, T.; Vissers, M. C.; Winterbourn, C. (2008). Ascorbate interacts with reduced glutathione to scavenge phenoxyl radicals in HL60 cells. Free. Radic. Biol. Med. 44, 1637-1644.

Dank, M.; Zaluski, J.; BaroneM C.; Valvere, V.; Yalcin, S. (2008). Randomized phase III study comparing irinotecan combined with 5-fluorouracil chemotherapy in naive patients with advanced Adeno carcinoma of the stomach or esophagogasric junction. Ann. Oncol., 19, 1450-1457.

De Bono, D.P., Yang, W.D. (1995). Exposure to low concentrations of hydrogen peroxide causes delayed endothelial cell death and inhibits proliferation of surviving cells. Atherosclerosis 114, 235-245.

El-Gendy, K. S.; Aly, N.M.; Mahmoud, F.H.; Kenawy, A. , El-Sebae, A.K. (2010). The role of vitamin $\mathrm{C}$ as antioxidant in protection of oxidative stress inducedbyimidacloprid. Food Chem. Toxicol. 48, 215-221.

El-Sayyad, H. I.; Ismail, M. F.; Shalaby, F.M.; Abou-El-Magd, R. F.; Gaur, R. L. (2009). Histopathological effect,s of cisplatin, doxorubicin and 5-flurouracil (5-FU) on the liver of male albino rats. Int. J. Biol. Sci. 5, 466-473.

Evans, D.L.; Dive, C. (1993). Effects of cisplatin on the induction of apoptosis in proliferating hepatoma cells and non proliferating immature thymocytes. Cancer Res. 53, 2133-2139.

Fawcett, D.W.; Jensh, R.P. (2002)."Bloom and Fawcett's Concise Histology". 2nd edn., Arnold, London, pp. 208-211.

Ferretti, G.; Bacchetti, T.; Masciangelo, S.; Pallotta, G. (2008). Lipid peroxidation in haemodialysis patients: Effect of vitamin C supplementation. Clin. Biochem. 41, 381-186.

Halliwell, B.; Cross, C.E. (1994). Oxygen-derived species: Their relation to human disease and environmental stress. Environ. Health Prespect. 102, 5-12.

Iraz, M., Ozerol, E.; Gulec, M.; Tasdemir, S.; Idiz, N.; Fadillioglu,. E (2006). Protective effect of caffeic acid phenethyl ester (CAPE) administration on cisplatin induced oxidative damage to liver in rat. Cell Biochem. Funct. 24(4), 357-61. 
Khaw, K.T.; Bingham, S.; Welch, A. (2001). Relation between plasma ascorbic acid and mortality in men and women in EPIC Norfolk prospective study: A prospective population study. Lancet. 357, 657-663.

Kim, K.S.; Joseph, B.; Inada, M.; Gupta, S. (2005). Regulation of hepatocyte engraftment and proliferation after cytotoxic drug-induced perturbation of the rat liver. Transplantation, 80, 653-659.

Kim, S.H.; Hong, K.O.; Chung, W.Y.; Hwang, J.K.; Park, K.K. (2004). Abrogation of cisplatin-induced hepatotoxicity in mice by xanthorrhizol is related to its effect on the regulation of gene transcription. Toxicol. Applied Pharmcol., 196, 346-355.

Koc, A.; Duru, M.; Ciralik, H.; Akcan, R.; Sogut, S. (2005). Protective agent, erdosteine, against cisplatin-induced hepatic oxidant injury in rats. Mol. Cell. Biochem. 278, 79-84.

Lee, C. K. ; Park, K.K. ; Lim, S. S. ; Park, J. H.; Chung, W.Y. (2007). Effects of the licorice extract against tumor growth and cisplatin-induced toxicity in a mouse xenograft model of colon cancer. Biol. Pharm. Bull. 30, 2191-2195.

Lee, W.M. (2003). Drug-induced hepatotoxicity. N. Engl. J. Med. 349, 474-485.

Liu, J.; Liu, Y.; Habeebu, S.M.; Klassen, C.D. (1998). Metallothionein (MT)-null mice are sensitive to cisplatin-induced hepatotoxicity. Toxicol. Appl. Pharmacol. 149, 24-31.

Lu, Y.; Cederbaum, A.I. (2006). Cisplatin-induced hepatotoxicity is enhanced by elevated expression of cytochrome P450 2E1. Toxicol. Sci., 89, 515-523.

Mansour, H. H.; Hafez, H. F.; Fahmy, N.M. (2006). Silymarin modulates Cisplatin 10 $\mathrm{mg} / \mathrm{kg}$ platin-induced oxidative stress and hepatotoxicity in rats. J. Biochem. Mol. Biol., 39, 656-661.

Mora, L.O.; Antunes, L.M.; Francescato, H.D.; Bianchi, M. (2003). The effects of oral glutamine on cisplatin-induced nephrotoxicity in rats. Pharmacol. Res., 47, 517522.

Oral, H.B.; George, J.T.; Haskard, D.O. (2000). Prevention of hydrogen peroxid and Cisplatin Induced Apoptosis by Intracellular Catalase Overexpression. Turk J Biol. 24, 685-696.

Oral, H. B. (1997). Use of gene transfer to protect cells from oxidant-mediated injury. PhD Thesis. Royal Postgraduate Medical School, Imperial College of Science, Technology and Medicine, University of London, London, United Kingdom.

Pal, S.; Sadhu, A.S.; Patra, S.; Mukherjea, K.K. (2008). Histological and biological assessment on the toxic level and antineoplastic efficacy of a synthetic drug Pt-ATP on the experimental animal models. J. Exp. Clin. Cancer Res., 27: 68-69.

Park, H.R.; Ju, E.J.; Jo, S.K.; Jung, U., Kim, S.H., Yee, S.T. (2009. Enhanced antitumor efficacy of cisplatin in combination with HemoHIM in tumor-bearing mice. BMC Cancer, 9:85-86.

Pratibha, R., Sameer, R.; Rataboli, P.V.; Bhiwgade, D.A.; Dhume, C.Y. (2006). Enzymatic studies of cisplatin induced oxidative stress in hepatic tissue of rats. Eur.J. Pharmcol. European J. Pharmacology, 532, 290-293.

Ramachandran, R.; Kakar, S. (2009). Histological patterns in drug-induced liver disease. $J$. Clin. Path. 62, 481-492.

Revindra, P.; Bhiwgade, D.A.; Kulkarni, S.; Rataboli, P.V.; Dhume, C.Y. (2010). Cisplatin induced histological changes in renal tissue of rat. JCAB .4(7),108-111. 
Saad, S. Y.; Najjar, T.A.; Alashari, M. (2004). Role of non selective adenosine receptor blockade and phosphodiesterase inhibition in cisplatin-induced nephrogonadal toxicity in rats. Clin. Exp. Pharmacol. Physiol., 31, 862-867.

Sweetman, S.C. (2002). "Antineoplastic and Immune-suppressant". In: Sweetman, SC. (Ed.), Martindale: The complete Drug reference, 33rd edn., Pharmaceutical Press, London, UK. pp. 525-527.

Venkatesan, P.N.; Rajendran, P.; Ekambaram, G.; Sakthisekaran, D. (2008). Combination therapeutic effect of cisplatin along with Solanum trilobatum on benzo (a)pyrene induced experimental lung carcinogenesis. Nat. Prod. Res., 22, 1094-1106.

William, C. (1995). Healthy eating: clarify advice about fruit and vegetables. Br. Med. J. 310,1453-1455.

Yace, A.; Atessahin, A.; Ceribasi, A.; Aksakal, M. (2007). Ellagic acid prevents cisplatin $10 \mathrm{mg} / \mathrm{kg}$ platin-induced oxidative stress in liver and heart tissue of rats. Basic Clin. Pharmacol. Toxicol. 101, 345-349.

Zhang, L.Y.; Wang, C.X. (1984). Histopathological and Histochemical studies on toxic effect of brodifacoum in mouse liver . Acta. Acad. Med. Sci. 6(5), 386-388. 